\title{
Epidemiology and Prevention of Allergy in Children
}

\section{Arnaldo Cantanii*}

Department of Pediatrics, Division of Allergy and Immunology, Roma University "La Sapienza", Italy

\begin{abstract}
In this paper we present 94 children affected with atopic dermatitis (AD), aggravated by respiratory allergy, asthma and/or allergic rhinitis (AR). $A D$ is a common disorder, frequently complicated by asthma-like symptoms, we debate either disorder and conclude that both AR and asthma can afflict most babies with AD, especially when both parents smoke. We confirm our previous statistics, according to which little children not fed breast milk may react to smallest doses of allergens.
\end{abstract}

Keywords: Atopic dermatitis; Allergy; Infections; Birth; Perinatal; Prenatal

\section{Introduction}

Several reports indicate an on-going increase in the incidence, prevalence and severity of atopic diseases both in industrialized and developing countries [1]. The prevalence of atopic disorders is steadily increasing especially in tåhe last 20 years [2]. Babies of atopic parents are particularly prone to develop atopic diseases, and for this reason they are called "high risk babies" [3-15]. During the last decade, great interest has been devoted to testing different measures to prevent the development of allergy and atopic disease in previously healthy subjects (primary prevention). Several studies shown that dietary and environmental measures, such as prolonged breast-feeding, delayed weaning and elimination of the house-dust mite exert a prophylactic effect on the development of atopic disease in this group of babies at high risk [4-9]. In addition, it has been shown that the avoidance of the most common offending foods (cow milk-CM, and peanuts) in the nursing mother's diet during the first three months of lactation induces a significantly lower prevalence of atopic dermatitis at the age of six months [9]. However, there is no general agreement on the most suitable formula when breast milk (BM) is not available. Some investigators have had encouraging results with soy protein formulas when BM was not available [4-6], while others had such using cow's milk protein hydrolysate formulas $[10,11]$.

\section{Environmental Factors}

It has been long known that a series of prenatal, neonatal and environmental factors such as season birth, home exposure to pets and tobacco smoking, viral infections, and dietary factors can be important in the phenotypic expression of atopy. The first weeks of life are extremely important for the expression of the allergic phenotype, because the mucosal and immune systems of new-borns and young infants may be particularly susceptible to a variety of environmental influences that should be avoided.

\section{Prenatal factors}

Several studies have suggested that infections during pregnancy and drugs administered to pregnant women are likely to lead to an increased risk of developing atopic allergy in babies. Michel et al. [16] reported that IgE concentration was higher in cord blood if the pregnant mothers had been administered progesterone. However, these elevated levels were not associated with an increased development of atopic disease in the infants [16]. Bjorksten et al. [17] found that the B-blocking agent metoprolol, intake during pregnancy, significantly increased the appearance of elevated neonatal IgE concentrations and the development of atopic symptoms before 18 months of age.
Antibodies to cow's milk and soy proteins have been detected in both the amniotic fluid and cord blood. Since the mothers had no antibodies to these allergens, it follows that the antibodies had been synthetized by the fetus $[18,19]$. In addition, it was also demonstrated that the fetus is capable of producing specific IgE antibodies to food allergens that were ingested by the mother during pregnancy [20]. However, a randomised study performed in a large series of pregnant women showed that a strict CM and egg free diet during the last 3 months of pregnancy had no effect on the development of atopy in the babies [21].

\section{Perinatal factors}

Instrumental delivery and use of drugs during delivery are factors over-represented in the history of children with atopic disease [22] Perinatal stress and early operation were suggested to increase the likelihood of subsequent atopic disease [23].

A massive first pollen season seems to imply higher risk for subsequent allergy than a normal pollen season [24]. The season of birth seems to be a predisposing factor in atopy sensitization. Subsequently a significantly higher incidence of sensitization to pollens in children born in March-May and to mites in children born in SeptemberOctober has been shown by several investigators $[25,26]$.

\section{Household exposure to allergens}

The house-dust mite appears to be the most common offending allergen in asthma, and an early exposure to this allergen is associated with a significant increase of the risk of asthma at the age of 11 [27]. Sporik et al. concluded that "increased exposure to dust mites and other indoor allergen may be a factor contributing to the recent increases in the morbidity and mortality associated with asthma" [27]. Wickman et al. [28] found that the exposure during the 2 first year of life to environmental tobacco smoke and home dampness was more frequently found among the house dust-mite sensitized children than among the controls. Arshad et al. [29] demonstrated in a prospective

*Corresponding author: Arnaldo Cantanii, Department of Pediatrics, Division of Allergy and Immunology, Roma University "La Sapienza", Italy, Tel: +39 06 49911; E-mail: acantani13@gmail.com

Received December 18, 2015; Accepted February 19, 2016; Published February 26, 2016

Citation: Cantanii A (2016) Epidemiology and Prevention of Allergy in Children. J Nutr Disorders Ther 6: 183. doi:10.4172/2161-0509.1000183

Copyright: $\odot 2016$ Cantanii A. This is an open-access article distributed under the terms of the Creative Commons Attribution License, which permits unrestricted use, distribution, and reproduction in any medium, provided the original author and source are credited. 
study on 1167 infants that some environmental factors such as maternal smoking, lower social classes, was interdependent and had a profound effect on the prevalence of asthma but not on other allergic disorders.

\section{Infections}

Viral infections frequently trigger asthmatic attacks in children. Their cytopathic effect on respiratory mucosal membranes might favour antigen penetration. Many studies have reported that several of these viruses, including respiratory syncytial virus, parainflenza (types 1-3), coronavirus, adenovirus, and cytomegalovirus may contribute to the development of allergic sensitization in the predisposed children. They could depress T-suppressor cells, which in turn allow increased IgE synthesis [30].

\section{Cigarette smoking}

Among the environmental factors favouring the development of atopic disease, cigarette smoke plays the primary role. Not only is tobacco smoke an irritant, but an increasing body of evidence also indicates that it predisposes to an increased susceptibility to respiratory viral infections [31,32]. Since these affections are asthmogenic, a vicious circle is started, especially in winter months in which a greater virus transmission is facilitated: parents' smoking---viral respiratory infections---asthma in the child. As a result, only a drastic inhibition of smoking can interrupt this circle. Several authors studying relationship between cigarette smoking and serum IgE levels reported higher IgE levels in adult smokers [33] and in infants of smoking atopic parents [34]. Smoking during pregnancy both seem to increase cord blood IgE concentrations and also the prevalence of atopic symptoms in infants $[16,35]$.

\section{Dietary Factors}

Mother's milk has been for millions of years the only source of feeding new-born babies and infants in the first years of life. Since the beginning of this century cow milk formulas have become a widely used breast milk (BM) substitute and solid food has been given to babies at a very early age. This dramatic change in early feeding habit has been thought to have played a role in increasing the prevalence of food allergy. IgE antibodies to foods (CM, egg, wheat, peanut, etc.) are present in a large proportion of children with atopic dermatitis [36], and positive challenge test to foods are positive in at least $50 \%$ of children with this disorder $[37,38]$. CM is the most common offending food both in gastrointestinal and in cutaneous manifestations. It has been recently estimated that $2 \%$ of children suffer from CM allergy [39].

The phenotypic expression and the natural history of food allergy vary widely according to patient's age, disease presentation and type of the offending food. In many children, the clinical course of the disease may be trivial, or mild, severe and frustrating in others, but even lifethreatening in some. A quite large proportion of children outgrow food allergy by the age of 2-3 years, however in many of them food allergy persists for life [40].

\section{Type of feeding in early life and food allergy}

Since the pioneering study by Grulee and Sandford which showed that atopic dermatitis was 7 times more frequent in bottle fed babies, than in breast fed ones [41], and the early studies by Glaser and Johnstone [42] and by Johnstone and Dutton [4] on the use of soy formulas for the prevention of atopic disease, a large debate in the literature occurred on the influence of early infant feeding and the development of food allergy in children. Forty years after the study by
Grulee and Sandford [41], Matthew et al. [5] conducted a prospective study of the development of eczema in infants of atopic parents, who were either subjected to an allergen-avoidance regimen from birth to six months or managed conventionally. The dietary measures included: breast feeding for 6 months, soy-bean formula when BM was not sufficient and selected weanings were only permitted between three and six months. The group on the allergen-avoidance regimen had less eczema at six months and one year than did the control group $(p=0.017)$ [5]. According to several studies, the preventive effect of human milk seems to be confined to atopic prone babies and to those who were breast fed for six months or more [6]. With a similar protocol by Matthew et al. [5] we have evaluated the prophylactic effect of dietary (mainly prolonged breast-feeding with soy formula supplements) and environmental measures on the development of atopic disease in newborns of atopic parents when they had a median age of 3 years and 8 months [8]. Only $14.5 \%$ of the study group compared to the $38.5 \%$ of the control group developed atopic manifestations $(\mathrm{p}<0.001)$. More recently, we confirmed a prevalence of $10 \%$ of atopic disease in 174 high risk babies followed up to 52 months with the same preventive program [43]. At the last follow-up (52 months), only 1 child (O.5\%) had atopic dermatitis, and $2(1 \%)$ had symptoms due to food allergy. These two children had urticarial due to CM allergy since both had IgE to $\mathrm{CM}$ and positive double blind placebo controlled food challenge to $\mathrm{CM}$. The prevalence of CM allergy, in this highly atopic prone baby, was thus only $1 \%$ [43]. In a multicentre study, which comprises 2.270 high risk babies we have shown that babies breast and/or soy-milk fed had at two years of age a significant lower prevalence of atopic diseases $(12 \%)$ in comparison with CM fed babies $(34 \%)(p<0.01)$ [44].

\section{Dietary manipulation during pregnancy}

According to several observations, antenatal sensitization to food antigens may occur $[18,19,45]$. Recent randomized studies did not show any preventive effect of dietary manipulation during pregnancy $[21,46]$.

\section{Dietary manipulation during lactation}

Since the beginning of this century Stuart [47] demonstrated that food antigens ingested by the mothers might pass into the BM, thus sensitizing the babies. More recently it has been shown that human milk contains as a mean $4.2 \mathrm{ng} / \mathrm{ml}$ of Beta-lacto-globulin which is 60.000 100.000 times lower than those of CM formulas [48]. The supplements of CM formulas occasionally given to full term healthy neonates in nurseries may sensitize predisposed babies, and the minute amount of CM proteins of human milk may subsequently act as a booster dose, triggering allergic reactions. The results of several studies support this hypothesis: CM allergy was significantly more common in babies who received supplements of $\mathrm{CM}$ formulas early in life in comparison to babies fully breast fed $[48,49]$.

The efficacy of a restrict diet during lactation has been shown by recent studies $[9,50]$. A prospective, randomized study showed that the exclusion of CM, egg, and fish during the first 3 months of lactation, was associated with a statistically significant reduction in both the prevalence and the severity of atopic dermatitis at the age of 3 and 6 months and a significantly lower cumulative prevalence of atopic disease at the age of 4 years [9].

\section{Type of weaning and food allergy}

Kajosaari and Saarinen [51,52] showed that total solid food elimination for the first six months of life, in addition to exclusive breast feeding, is prophylactic for atopic disease in children who are 
at hereditary risk. It has been shown by Fergusson et al. [53] that rates of eczema increased in almost direct proportion to the number of different types of solid food given to the child in the first 4 months of life: children given five or more different solid foods had over twice the risk of eczema when compared with children given no solid food [53].

\section{Cow milk substitutes}

There is no agreement on the most suitable formula if the mother cannot breast feed [54-57]. Soy-bean formulas have been employed for many years for the prevention of food allergy, in high risk babies, when $\mathrm{BM}$ is not available with controversy results $[5,8,43,58]$. More recently Bardare et al. [58] studied a high number of children and demonstrated that the infants at risk of atopy whose parents complied whit the prescribed diet (prolonged breast-feeding with soy formula supplements, etc.) were found to have a lower incidence of atopy during the first year of life (13.3\%) than infants whose parents had ignored the prescribed diet $(54.7 \%)$ or infants whose parents were offered no dietary recommendation (28.9\%) [58]. Soy proteins are immunogenic, but according to experimental and clinical studies they are less immunogenic and allergenic than CM proteins [36,59-63]. Soy protein formulas are nutritionally adequate, the taste is well accepted by most infants, and the formulas are less expensive than extensively hydrolysed formulas.

In the last few years, several studies have been published on the use of hydrolysate formulas (HFs) for the prevention of CM allergy, in high risk babies, when $\mathrm{BM}$ is not available $[64,65,50,10]$. These products widely vary in the degree of hydrolysis: the highly casein HFs contains peptides with molecular weight (m.w.) below 1.500 K.D., whereas the whey partially HFs contain a significant amount of peptides with m.w. more than 4.000 daltons and $5 \%$ of the peptides has m.w. even more than 15.000 daltons [66]. Due to the significant amount of immune reactive epitopes and intact CM proteins, partially HFs may be not only allergenic but even immunogenic in a predisposed host $[55,67,68]$. In two studies highly casein HFs have been employed [11,69], in others a whey partially HF $[64,65]$ and in one an ultra-filtrate whey HF [70]. Chandra et al. [64] showed that the feeding of whey proteins-partially HF to infants with a positive family history of atopy significantly decreased the prevalence of atopic disease in these babies compared with that found in soy or cow milk fed infants. However in this study there was no evidence that $\mathrm{CM}$ allergy was prevented. Of the five $\mathrm{HF}$ fed infants who developed atopic symptoms, four had a positive skin test to CM proteins thus suggesting that sensitization to milk proteins may occur in infants receiving this formula [64]. In another study by Vandenplas [65] performed in high risk babies fed either a whey partially $\mathrm{HF}$ or a CM formula, the prevalence of $\mathrm{CM}$ allergy at six months of age was $15,6 \%$ in the HF fed group and $40 \%$ in the CM formula fed group. The $40 \%$ prevalence of CM allergy, reported in the CM fed babies, is unusually high and it is not in agreement with other studies $[3,8,43,45]$. Therefore serious doubt arises on the diagnostic criteria employed by these Aa for the diagnosis of CM allergy and the $15,6 \%$ prevalence of CM allergy, found in the partially whey HF fed babies, confirms that this product can be immunogenic. More recently, we have described several cases of anaphylaxis, which occurred following the first feed with a partial HF in breast fed babies, who have been given the same product in the nursery [68].These data strongly suggest that partial HFs can be immunogenic when given in the first days of life. In a randomised study, an extensively soya-based protein HF was given in association with several environmental measures [71]. At the age of 12 months atopic diseases had developed in $40 \%$ of the infants in the control group and in $14 \%$ of the infants in prophylaxis. Asthma and eczema were present respectively in $19 \%$ and $7 \%$ of the babies of the control group and in $7 \%$ and $7 \%$ of the infants in prophylaxis. Only one baby of the prophylactic group had CM allergy [71].

\section{Conclusion}

In conclusion, several studies indicate that it is possible to prevent the onset of atopic dermatitis, CM allergy and food allergy with some dietary manipulations, however further studies are necessary to investigate the role of partially HFs for the prevention of CM allergy in atopic prone neonates.

\section{References}

1. Kjellman NIM, Andrrae S, Croner S, Hattevig G, Falth-Magnusson K et al. (1988) Epidemiology and prevention of allergy. Immunol Allergy Practice 10: 393.

2. Burr ML, Butland BK, King S, Vaughan-Williams E (1989) Changes in asthma prevalence: two surveys 15 years apart. Arch Dis Child 64: 1452-1456.

3. Van Asperen PP, Kemp AS (1989) The natural history of IgE sensitisation and atopic disease in early childhood. Acta Paediatr Scand 78: 239-245.

4. Johnstone DE, Dutton AM (1966) Dietary prophylaxis of allergic disease in children. N Engl J Med 274: 715-719.

5. Matthew DJ, Taylor B, Norman PA, Turner MW, Soothill JF (1977) Prevention of eczema. Lancet i: 321

6. Saarinen UM, Kajosaari M, Backman A, Siimes MA (1979) Prolonged breastfeeding as prophylaxis for atopic disease. Lancet 2: 163-166.

7. Businco L, Marchetti F, Pellegrini G, Perlini R (1983) Predictive value of cord blood IgE levels in 'at-risk' newborn babies and influence of type of feeding. Clin Allergy 13: 503-508.

8. Businco L, Cantani A, Meglio P, Bruno G (1987) Prevention of atopy: results of a long-term (7 months to 8 years) follow-up. Ann Allergy 59: 183-186.

9. Hattevig G, Kjellman B, Sigurs N, Björkstén B, Kjellman NI (1989) Effect of maternal avoidance of eggs, cow's milk and fish during lactation upon allergic manifestations in infants. Clin Exp Allergy 19: 27-32.

10. Halken S, Høst A, Hansen LG, Osterballe O (1993) Preventive effect of feeding high-risk infants a casein hydrolysate formula or an ultrafiltrated whey hydrolysate formula. A prospective, randomized, comparative clinical study. Pediatr Allergy Immunol 4: 173-181.

11. Zeiger RS, Heller S, Mellon MH, Forsythe AB, O'Connor RD, et al. (1989) Effect of combined maternal and infant food-allergen avoidance on development of atopy in early infancy: a randomized study. J Allergy Clin Immunol 84: 72-89.

12. Lubs ML (1972) Emperic risks for genetic counseling in families with allergy. $J$ Pediatr 80: 26-31.

13. Bousquet J, Michel FB (1983) Prediction of allergic risk in infants. In Businco Luisa (ed), Advances in Pediatric Allergy. Amsterdam: Elsevier Science Publishers BV 55.

14. Kjellman NI, Croner S (1984) Cord blood IgE determination for allergy prediction--a follow-up to seven years of age in 1,651 children. Ann Allergy 53: 167-171.

15. Lilja G, Magnusson CG, Johansson SG, Kusoffsky E, Oman H (1992) Neonata IgE levels and three different blood sampling techniques. Allergy 47: 522-526.

16. Michel FB, Bousquet J, Greillier P, Robinet-Levy M, Coulomb Y (1980) Comparison of cord blood immunoglobulin $\mathrm{E}$ concentrations and maternal allergy for the prediction of atopic diseases in infancy. J Allergy Clin Immunol 65: $422-430$

17. Björkstén B, Finnström O, Wichman K (1988) Intrauterine exposure to the betaadrenergic receptor-blocking agent metoprolol and allergy. Int Arch Allergy Appl Immunol 87: 59-62.

18. Singer AD, Hobel CJ, Heiner DC (1974) Evidence for secretory IgA and IgE in utero. J Allergy Clin Immunol 53: 94

19. Frick OL, German DF, Mills J (1979) Development of allergy in children. Association with virus infections. J Allergy Clin Immunol 63: 228-241. 
20. Miller DL, Hiravonen T, Gitlin D (1973) Synthesis of IgE by the human conceptus. J Allergy Clin Immunol 52: 182-188

21. Fälth-Magnusson K, Kjellman NI (1992) Allergy prevention by materna elimination diet during late pregnancy--a 5-year follow-up of a randomized study. J Allergy Clin Immunol 89: 709-713.

22. Golding J, Peters TJ (1987) The epidemiology of childhood eczema: I. A population based study of associations. Paediatr Perinat Epidemiol 1: 67-79.

23. Björkstén B, Kjellman NI (1987) Perinatal factors influencing the development of allergy. Clin Rev Allergy 5: 339-347.

24. Björkstén F, Suoniemi I (1976) Dependence of immediate hypersensitivity on the month of birth. Clin Allergy 6: 165-171.

25. Soothill JF, Stokes CR, Turner MW, Norman AP, Taylor B (1976) Predisposing factors and the development of reaginic allergy in infancy. Clin Allergy 6: 305319.

26. Businco L, Cantani A, Farinella F, Businco E (1988) Month of birth and grass pollen or mite sensitization in children with respiratory allergy: a significant relationship. Clin Allergy 18: 269-274.

27. Sporik R, Holgate ST, Platts-Mills TA, Cogswell JJ (1990) Exposure to housedust mite allergen (Der $\mathrm{p} \mathrm{I}$ ) and the development of asthma in childhood. A prospective study. N Engl J Med 323: 502-507.

28. Wickman M, Nordvall SL, Pershagen G (1992) Risk factors in early childhood for sensitization to airborne allergens. Pediatr Allergy Immunol 3: 128.

29. Arshad SH, Hide DW (1992) Effect of environmental factors on the development of allergic disorders in infancy. J Allergy Clin Immunol 90: 235-241.

30. Stark JM, Busse MM (1991) Respiratory virus infection and airway hyperreactivity in children. Pediatr Allergy Immunol 2: 95.

31. Fergusson DM, Horwood LJ, Shannon FT (1980) Parental smoking and respiratory illness in infancy. Arch Dis Child 55: 358-361.

32. Kark JD, Lebiush M, Rannon L (1982) Cigarette smoking as a risk factor for epidemic a(h1n1) influenza in young men. N Engl J Med 307: 1042-1046.

33. Wittig HJ, McLaughlin ET, Leifer KL, Belloit JD (1978) Risk factors for the development of allergic disease: analysis of 2,190 patient records. Ann Allergy 41: 84-88.

34. Kjellman NI (1981) Effect of parental smoking on IgE levels in children. Lancet 1: $993-994$.

35. Magnusson CG (1986) Maternal smoking influences cord serum IgE and $\operatorname{lgD}$ levels and increases the risk for subsequent infant allergy. J Allergy Clin Immunol 78: 898-904.

36. Giampietro PG, Ragno V, Daniele S, Cantani A, Ferrara M, et al. (1992) Soy hypersensitivity in children with food allergy. Ann Allergy 69: 143-146.

37. Sampson HA, McCaskill CC (1985) Food hypersensitivity and atopic dermatitis: evaluation of 113 patients. J Pediatr 107: 669-675.

38. Meglio P, Giampietro PG, Farinella F, Cantani A, Businco L (1989) Persona experience in the diagnostic procedures in children with atopic dermatitis and food allergy. Allergy 9: 165-173.

39. Høst A, Halken S (1990) A prospective study of cow milk allergy in Danish infants during the first 3 years of life. Clinical course in relation to clinical and immunological type of hypersensitivity reaction. Allergy 45: 587-596.

40. Businco L, Ragno V, Cantani A (1991) Natural History of IgE mediated food allergy in fully breast fed babies. Report of 21 cases with follow-up to 19 Years. Pediatr Allergy Immunol 2: 131.

41. Grulee CG, Sanford HN (1936) The influence of breast and artificial feeding on infantile eczema. J Pediatr 9: 223

42. Glaser J, Johnstone De (1953) Prophylaxis of allergic disease in the newborn J Am Med Assoc 153: 620-622.

43. Bruno G, Milita O, Ferrara M, Nisini R, Cantani A, et al. (1993) Prevention of atopic diseases in high risk babies (long-term follow-up). Allergy Proc 14: 181-186.

44. Bruno G, Giampietro PG, Businco L (1992) Multicentre study on the prevention of atopy in high risk babies two years follow-up. Pediatric Research 33: A.

45. Businco L, Marchetti F, Pellegrini G, Cantani A, Perlini R (1983) Prevention of atopic disease in "at-risk newborns" by prolonged breast-feeding. Ann Allergy 51: $296-299$

46. Lilja G, Dannaeus A, Foucard T, Graff-Lonnevig V, Johansson SGO, et al. (1989) Effect of maternal diet during late pregnancy and lactation on the development of atopic disease in infants of 18 months of age - in vivo results. Clin Exp Allergy 19: 473

47. Stuart HC (1923) The excretion of foreign protein in human milk. AJDC 25: 135

48. Høst A, Husby S, Osterballe O (1988) A prospective study of cow's milk allergy in exclusively breast-fed infants. Incidence, pathogenetic role of early inadvertent exposure to cow's milk formula, and characterization of bovine milk protein in human milk. Acta Paediatr Scand 77: 663-670.

49. Stintzing G, Zetterström R (1979) Cow's milk allergy, incidence and pathogenetic role of early exposure to cow's milk formula. Acta Paediatr Scand 68: 383-387.

50. Zeiger RS, Heller S, Sampson HA (1992) Genetic and environmental factors affecting the development of atopy from birth through age 4 in a prospective randomized controlled study of dietary avoidance. J Allergy Clin Immunol 89 192.

51. Kajosaari M, Saarinen UM (1983) Prophylaxis of atopic disease by six months' total solid food elimination. Evaluation of 135 exclusively breast-fed infants of atopic families. Acta Paediatr Scand 72: 411-414.

52. Saarinen UM, Kajosaari M (1980) Does dietary elimination in infancy prevent or only postpone a food allergy? A study of fish and citrus allergy in 375 children. Lancet 1: 166-167.

53. Fergusson DM, Horwood LJ, Beautrais AL, Shannon FT, Taylor B (1981) Eczema and infant diet. Clin Allergy 11: 325-331.

54. Businco L, Bellanti J (1993) Food allergy in childhood. Hypersensitivity to cows' milk allergens. Clin Exp Allergy 23: 481-483.

55. Businco L, Dreborg S, Einarsson R, Giampietro PG, Høst A, et al. (1993) Hydrolysed cow's milk formulae. Allergenicity and use in treatment and prevention. An ESPACI position paper. European Society of Pediatric Allergy and Clinical Immunology. Pediatr Allergy Immunol 4: 101-111.

56. Dreborg S, Businco L, Høst A, Wahn U (1993) Hypoallergenic formulae. The Executive Committee of ESPACI. Acta Paediatr 82: 901.

57. Businco L, Bruno G, Giampietro PG, Ferrara M (1993) Is prevention of food allergy worthwhile? J Investig Allergol Clin Immunol 3: 231-236.

58. Bardare M, Vaccari A, Allievi E, Brunelli L, Coco F, et al. (1993) Influence of dietary manipulation on incidence of atopic disease in infants at risk. Ann Allergy 71: 366-371.

59. May CD, Remigio L, Bock SA (1980) Usefulness of measurement of antibodies in serum in diagnosis of sensitivity to cow milk and soy proteins in early childhood. Allergy 35: 301-310

60. Sampson HA (1988) Jerome Glaser lectureship. The role of food allergy and mediator release in atopic dermatitis. J Allergy Clin Immunol 81: 635-645.

61. Piacentini GL, Benedetti M, Spezia E, Boner AL, Bellanti JA (1991) Anaphylactic sensitizing power of selected infant formulas. Ann Allergy 67: 400-402.

62. Businco L, Bruno G, Giampietro PG, Cantani A (1992) Allergenicity and nutritional adequacy of soy protein formulas. J Pediatr 121: S21-28.

63. Businco L (1993) Is soy allergy overstimed? Pediatr Allergy Immunol 7: 73.

64. Chandra RK, Hamed A (1991) Cumulative incidence of atopic disorders in high risk infants fed whey hydrolysate, soy, and conventional cow milk formulas. Ann Allergy 67: 129-132.

65. Vandenplas Y, Hauser B, Van den Borre C, Sacre L, Dab I (1992) Effect of a whey hydrolysate prophylaxis of atopic disease. Ann Allergy 68: 419-424.

66. Businco L, Cantani A (1990) Hypoallergenic Formulae Allergy Today 1990;3:315.

67. Ragno V, Giampietro PG, Bruno G, Businco L (1993) Allergenicity of milk protein hydrolysate formulae in children with cow's milk allergy. Eur J Pediatr 152: 760-762.

68. Businco L, Lucenti P, Arcese G, Ziruolo G, Cantani A (1994) Immunogenicity of a so-called hypoallergenic formula in at-risk babies: two case reports. Clin Exp Allergy 24: 42-45.

69. Chandra RK, Puri S, Hamed A (1989) Influence of maternal diet during lactation 
and use of formula feeds on development of atopic eczema in high risk infants. BMJ 299: 228-230

70. Businco L, Cantani A (1990) Prevention of childhood allergy by dietary manipulation. Clin Exp Allergy 3: 9-14.
71. Arshad SH, Matthews S, Gant C, Hide DW (1992) Effect of allergen avoidance on development of allergic disorders in infancy. Lancet 339: 1493-1497. 